\title{
Učitelé výtvarné výchovy a jejich znalosti kurikula
}

\author{
Art teachers and their knowledge of curriculum \\ Petra Šobáňová
}

\begin{abstract}
Abstrakt: Příspěvek prezentuje dílčí výsledky empirického výzkumu, který zkoumá znalosti kurikula výtvarné výchovy u učitelů základních škol. Cílem šetření je zjistit, zda reflektují celou šíri učiva oboru a zda se v jejich pedagogickém uvažování projevuje jeho změna v Rámcových vzdělávacích programech pro základní vzdělávání. Zajímá nás, co učitelé považují za učivo a jak je formulují. Výsledky ukazují na neznalost kurikula výtvarné výchovy (za učivo se považují výtvarné postupy či techniky, př́ípadně praktické výtvarné činnosti a jejich náměty) a přehlížení obsahové domény ověrování komunikačních účinků. Výzkumná data byla získána prostřednictvím dotazníkového šetření, dílčí výsledky jsou interpretovány $\mathrm{v}$ širším kontextu problematiky výtvarné edukace.
\end{abstract}

Klíčová slova: výtvarná výchova, znalosti kurikula, učivo výtvarné výchovy

\begin{abstract}
In this contribution are presented sub outcomes of an empirical study dealing with the primary-school art-teachers' ${ }^{6}$ knowledge of curriculum. The aim of the research is to ascertain whether the teachers comply with the subject curriculum and whether they pedagogically reflect its change in terms of Framework Education Programme for Basic Education. The topic in question is the teachers ${ }^{6}$ understanding and formulation of the term „curriculum“. The outcomes prove ignorance of the art curriculum (procedures, techniques or practical activities and their themes are considered to be the curriculum), and failing to take the verification of communicative effect into consideration. The data was obtained by means of questionnaires, and the sub outcomes are interpreted in a wider context of art education.
\end{abstract}

Keywords: art education, curriculum knowledge, curriculum of art education

\section{1 Úvod}

Vzdělávací obsah oboru výtvarná výchova (dále VV) se během dvou staletí existence oboru přirozeně proměňoval: původní technicistně zaměřené kreslení proměnily pedocentrické tendence 20. století se zájmem o dětskou psychiku a výtvarný projev dítěte. Při tvorbě vzdělávacího obsahu VV pro nově zaváděné Rámcové vzdělávací programy pro základní vzdělávání (RVP ZV) se projevil vliv pluralitní postmoderní kultury, sémiotiky, vizuálních studií a progresivních proudů výtvarně pedagogického myšlení zabývajících se vizualitou.

Specifika oboru vyjádřená v RVP ZV spočívají ve schopnosti pracovat s vizuálně obrazným vyjádřením (VOV) a v experimentálním zacházení s ním (Pastorová \& Vančát, 2004). Žák se učí chápat fungování znakových systémů a uvědomovat si vlastní možnosti při jejich tvorbě a modifikaci. Praktické výtvarné dovednosti jsou součástí tvůrčího procesu, doplněného přirozeně o komunikační, resp. interpretační složku. 
Na rozdíl od minulosti, kdy bylo učivo oboru členěno podle postupů, námětových okruhů či výtvarných technik, je vzdělávací obsah VV v RVP ZV členěn do tří obsahových domén (dále OD):

- rozvíjení smyslové citlivosti;

- uplatňování subjektivity;

- ověřování komunikačních účinků (Jeřábek \& Tupý, 2007).

\section{Výzkumná oblast, téma a cíle šetření}

Výzkum z oblasti výtvarné pedagogiky zkoumá znalosti kurikula u učitelů VV na základních školách (ZŠ), a to v kontextu „poznatkové báze učitelství“, jak o ní uvažuje L. S. Shulman (Janík, 2007, s. 27). Cílem je zjistit, zda učitelé reflektují celou šíři učiva VV a zda se v jejich pedagogickém uvažování projevuje jeho změna v RVP ZV. Zajímá nás, co učitelé považují za učivo VV a jak je formulují. Zkušenosti z praxe, stejně jako výzkumy (např. Hazuková, 2005), totiž ukazují, že učitelé VV vzdělávací obsah, prŕípadně oborovou terminologii často neznají či nepoužívají, nerozlišují didaktické kategorie specifické pro VV a ve výtvarné edukaci se opomíjejí aktivity související s ověřováním komunikačních účinků VOV. Cílem první části šetření bylo poznání současného stavu, sledování vlivu různých determinantů (např. aprobovanost či délka praxe) bude vyhodnoceno teprve v další fázi.

\section{Výzkumné otázky}

- Co učitelé VV považují za učivo svého vzdělávacího oboru?

- Jakému učivu se aktuálně s žáky věnují a jakým způsobem tento konkrétní vzdělávací obsah formulují?

\section{Metodologické postupy}

Po teoretické analýze bylo stanoveno téma šetření, tedy znalosti kurikula VV u učitelů ZŠ. Zvolený problém byl zkoumán kvantitativními metodami, data jsme shromáždili pomocí dotazníků; formulace otázek vyplynuly z pilotáže:

- Co je podle Vás učivem VV?

- Jakému konkrétnímu učivu se ve VV právě věnujete?

Jde o otázky otevřené, respondenti mohli uvádět více odpovědí; ty byly po vyhodnocení sdruženy do širších kategorií. Dotazník byl ověřen v rámci předvýzkumu (188 respondentů), jehož dílčí výsledky zde prezentujeme. Výzkum dále probíhá v obvyklých fázích shromažd'ování dat (více než 600 dotazníků), jejich analýza na popisné úrovni, vztahová analýza a vyvození závěrů. Získané informace byly zobecněny, graficky znázorněny a interpretovány, vztahy mezi proměnnými budou dále ověřovány testem statistické významnosti.

\section{Základní soubor, výzkumný vzorek}

Cíle výzkumu a formulace jeho tématu implikují povahu základního souboru - jde o učitele, kteří vyučují výtvarnou výchovu na 1. a 2. stupni ZŠ (at' již jako aprobovaní, či nikoliv). Jako výzkumný vzorek byli náhodně vybráni učitelé VV působící v roce 2010-2011 na nejrůznějších školách v celé ČR. 


\section{Výsledky}

Pro prezentaci výsledků používáme tabulky četností (viz tabulka 1-3) tak, aby co nejlépe organizovaly analýzu a strukturovaly prezentaci výsledků.

Tabulka 1

Otázka číslo 1

\begin{tabular}{|l|l|c|c|}
\hline \multicolumn{2}{|l|}{ Otázka č. 1: Co je podle Vás učivem VV? } & $\begin{array}{l}\text { Počet } \\
\text { odpovědí }\end{array}$ & $\begin{array}{l}\text { Procentuální } \\
\text { vyjádření }\end{array}$ \\
\hline 1. & $\begin{array}{l}\text { Výtvarné vyjadřovací prostředky (souvisí s OD uplatňování } \\
\text { subjektivity) }\end{array}$ & 87 & $21,4 \%$ \\
\hline 2. & Sebevyjádření žáků (souvisí s OD uplatňování subjektivity) & 53 & $13,1 \%$ \\
\hline 3. & Výtvarné myšlení (souvisí s OD rozvíjení smyslové citlivosti) & 46 & $11,3 \%$ \\
\hline 4. & Estetické hodnoty & 41 & $10,1 \%$ \\
\hline 5. & Fantazie & 38 & $9,4 \%$ \\
\hline 6. & Poznatky z dějin umění & 34 & $8,4 \%$ \\
\hline 7. & Praktické výtvarné či manuální dovednosti & 26 & $6,4 \%$ \\
\hline 8. & Rozvoj osobnosti žáka a jeho žádoucích vlastností či schopností & 26 & $6,4 \%$ \\
\hline 9. & Tvořivost & 22 & $5,4 \%$ \\
\hline 10. & Obecná kulturní iniciace, vztah ke kultuře (nejen výtvarné) & 20 & $4,9 \%$ \\
\hline 11. & Odpovědi reflektují RVP & 5 & $1,2 \%$ \\
\hline 12. & Relaxace & 5 & $1,2 \%$ \\
\hline 13. & Jiné & 3 & $0,7 \%$ \\
\hline & \multicolumn{2}{|c|}{. } & 5 \\
\hline
\end{tabular}

Celkem 406 odpovědí, $99,9 \%$

Tabulka 2

Otázka číslo 2

\begin{tabular}{|l|l|c|c|}
\hline \multicolumn{2}{|l|}{ Otázka č. 2: Co je podle Vás učivem VV? } & $\begin{array}{l}\text { Počet } \\
\text { odpovědí }\end{array}$ & $\begin{array}{l}\text { Procentuální } \\
\text { vyjádření }\end{array}$ \\
\hline 1. & Komplexní uvažování o učivu (reflexe učiva dle RVP jako celku) & 5 & $1,2 \%$ \\
\hline 2. & Rozvíjení smyslové citlivosti & 141 & $34,7 \%$ \\
\hline 3. & Uplatňování subjektivity & 255 & $62,8 \%$ \\
\hline 4. & Ověřování komunikačních účinků & 2 & $0,5 \%$ \\
\hline 5. & Jiné & 3 & $0,7 \%$ \\
\hline \multicolumn{2}{|r|}{ Celkem 406 odpovědí, 99,9\% } \\
\hline
\end{tabular}

Tabulka 3

Otázka číslo 3

\begin{tabular}{|l|l|c|c|}
\hline & $\begin{array}{l}\text { Otázka č. 3: Jakému konkrétnímu učivu se ve VV právě } \\
\text { věnujete? }\end{array}$ & $\begin{array}{l}\text { Počet } \\
\text { odpovědí }\end{array}$ & $\begin{array}{l}\text { Procentuální } \\
\text { vyjádření }\end{array}$ \\
\hline 1. & Respondenti uvedli konkrétní námét & 141 & $48,3 \%$ \\
\hline 2. & $\begin{array}{l}\text { Respondenti uvedli výtvarný problém, který lze přiřadit k... } \\
\text { 2.a ... OD rozvíjení smyslové citlivosti } \\
\text { 2.b ... OD uplatňování subjektivity } \\
\text { 2.c ... OD ověřování komunikačních účinků }\end{array}$ & 139 & $47,6 \%$ \\
\cline { 2 - 4 } & $\begin{array}{l}\text { Respondenti uvedli, že se věnují výzdobě školy či výrobě } \\
\text { dekoračních dárkových předmětů }\end{array}$ & 116 & $16,6 \%$ \\
\hline \multicolumn{3}{|l|}{ Celkem 292 odpovědí, 100 \% } \\
\hline
\end{tabular}




\section{Odpovědi na výzkumné otázky}

7.1 Co učitelé VV považují za učivo svého vzdělávacího oboru?

- $21,4 \%$ respondentů uvedlo, že za učivo VV považují některý z výtvarných vyjadřovacích prostředků (koresponduje s OD uplatňováni subjektivity). Plných $97 \%$ z nich uvedlo, že za učivo VV považují některý z výtvarných postupů či konkrétních technik.

- $\quad 13,1 \%$ respondentů považuje za učivo VV ,sebevyjádření žáků“, což souvisí s OD uplatňování subjektivity. Respondenti uváděli „seberealizace, vyjádření pocitů“ aj.

- $\quad 11,3$ \% respondentů uvedlo, že za učivo VV pokládají „výtvarné myšlení“ (souvislost $\mathrm{s}$ rozvíjením smyslové citlivosti) a vyjadřovalo se v pojmech „výtvarné cítění, vnímavost pro barvu, vlastnosti materiálü“aj.

- $10,1 \%$ považuje za učivo VV „estetično, estetické cítění, vkus“, 9,4\% rozvoj fantazie, $8,4 \%$ fakta z dějin umění („malíríi a jejich díla, výtvarné slohy“). 6,4\% praktické výtvarné či manuální dovednosti (,„práce s nástroji, zručnost“), 6,4 \% rozvoj osobnosti žáka a jeho žádoucích vlastností či schopností (,vưle, píle, plánování, pečlivost, trpělivost" ), 5,4 \% tvořivost; 4,9 \% uvažuje o pěstování vztahu ke kultuře (nejen výtvarné). 1,2\% reflektuje RVP (,vzdělávací obsah je dán RVP, naplňování klíčových kompetencí“), 1,2 \% za učivo považuje „relaxaci“.

- Při odpovědích na otázku se 1,2 \% respondentů vyjadřovalo o učivu VV komplexním způsobem a explicitně reflektovalo RVP. U 62,8 \% výpovědí lze nalézt souvislost $\mathrm{s}$ uplatňováním subjektivity, u 34,7\% s rozvijením smyslové citlivosti, souvislost s ověrováním komunikačních účinků u 0,5\%.

\subsection{Jakému učivu se učitelé aktuálně šáky věnuji a jakým způsobem tento konkrétní vzdělávací obsah formulují?}

- 48,3 \% respondentů uvedlo konkrétní námět, z toho plných $68 \%$ byly náměty zima či Vánoce.

- 47,6 \% uvedlo nějaký výtvarný problém, a proto zde lze nalézt sledovanou souvislost $\mathrm{s}$ učivem dle RVP, kterou jsme se pokusili vyjádřit:

- Souvislost s rozvíjením smyslové citlivosti - 16,6 \% výpovědí

- Souvislost s uplatňováním subjektivity - 83,5\% výpovědí. Učitelé uvedli bud' konkrétní výtvarný postup (48,3\%), techniku či materiál (31,9\%), nebo žánr $(20 \%)$.

- Souvislost s ověrováním komunikačních účinki̊ jsme nenalezli u žádné z odpovědí.

- 4,1\% respondentů uvedla, že se věnují výzdobě školy a výrobě dekorativních dárkových předmětů.

\section{Diskuse}

V první řadě je třeba uvést, že respondenti nemají ujasněn význam didaktických kategorií, a tak místo učiva často uváděli obecné či specifické cíle výtvarné edukace či její efekty, konkrétní úkoly nebo náměty. Znalosti kurikula jsou u učitelů VV nedostatečné a učitelé nemají jasno $\mathrm{v}$ tom, co je ve $\mathrm{VV}$ učivem. Jedním $\mathrm{z}$ důvodů může být i specifikum výtvarné edukace, spočívající v tom, že k žákovu poznávání a učení se využívá jeho vlastní „tvořivě 
expresivní činnost“" (Slavík, Lukavský, \& Lajdová, 2008). Vzdělávací obsah VV se realizuje při kreativních činnostech žáků, žáci dokonce „sami navrhují a tvoří obsahové reprezentace“ (tamtéž, s. 114). Zmíněné specifikum se projevilo, když jsme se pokusili jednotlivá vyjádření respondentů přiřadit $\mathrm{k}$ jednotlivým OD - pak se ukazuje, že většina učitelů považuje za učivo VV obsah formulovaný v OD uplatňování subjektivity $(62,8 \%)$ nebo rozvíjení smyslové citlivosti $(34,7 \%)$. Souvislost s OD ověrováni komunikačních účinků se nám však nepodařilo najít u žádné z odpovědí, což ukazuje na přetrvávající prrehlížení tohoto obsahu. Dá se předpokládat, že také v praxi učitelé zanedbávají pěstování komunikačních schopností žáků či schopnost interpretace VOV.

Výše uvedená zjištění potvrzují i odpovědi na druhou výzkumnou otázku. 48,3 \% respondentů považuje za učivo konkrétní námět, což je nepochopením jeho postavení v systému didaktických kategorií VV. Nadále přetrvávají stereotypní náměty - vzhledem $\mathrm{k}$ tomu, že šetření probíhalo v zimních měsících, plných 68 \% respondentů (udávajících jako „učivo“ námět) uvedlo náměty zima či Vánoce. Pouze pro úplnost dodáváme známý fakt, že učitel má při volbě námětů plnou autonomii.

47,6 \% respondentů uvedlo jako učivo určitý výtvarný problém, a zde již lze sledovanou souvislost $\mathrm{s}$ učivem dle RVP ZV nalézt. Naprostou převahu má přitom učivo OD uplatňování subjektivity (83,5 \% výpovědí), což znamená, že VV je v myšlení učitelů postavena především na praktických tvưrčích činnostech žáků, souvislost s ověrováním komunikačních účinki̊ jsme nenalezli u žádné z odpovědí - přestože všechny tři OD by měly mít rovnocenné postavení a učitel by měl vymezovat obsah nejen volbou praktických úkolů, ale také „usměrňováním reflexe a interpretace žákovské tvorby“ (Slavík, Lukavský, \& Lajdová, 2008, s. 114).

Přestože v souvislosti se startem reformy a tvorbou školních vzdělávacích programů učitelé poměrně nedávno formulovali osnovy oboru, existenci RVP ZV explicitně reflektovalo pouhé $1,2 \%$ respondentů. Terminologii RVP ZV respondenti nepouživají ${ }^{1}$ a pouhé procento $\mathrm{z}$ nich uvažuje o učivu VV komplexním způsobem. Na úplný závěr dodejme, že 4,1 \% respondentů uvedla, že se jako učivu (!) věnují výzdobě školy či výrobě dekorativních dárkových předmětů. Letitý problém devalvování VV tedy stále nemizí - zvláště uvědomíme-li si, že respondenti mají obvykle tendenci ukazovat své působení v lepším světle.

\section{Závěr}

Výsledky výzkumu ukazují, že učitelé VV nedisponují dostatečnými znalostmi kurikula a o učivu neuvažují komplexně, nýbrž v jednotlivostech. Závažným zjištěním je ignorance celé obsahové domény ověrování komunikačních účinků; ta přitom tvoří plnou třetinu učiva oboru v RVP ZV. Zjištěné nedostatky mají jistě zásadní vliv na kvalitu výtvarné edukace, protože ta je závislá na tom, zda učitel ví, čemu má vyučovat, a zda učivu rozumí. Nekompetence učitelů negativně ovlivňuje i postavení VV v systému základního vzdělávání, protože k principům RVP patří podpora profesní zodpovědnosti učitelů za výsledky vzdělávání a pozici svého oboru. Nedostatky v poznatkové bázi učitelství ohrožují plnění vzdělávacích cílů VV a zpochybňují požadavek autonomie učitelů.

\footnotetext{
${ }^{1}$ Funkční slovník učitelů (Hazuková, 2005) se naproti tomu opírá mj. o (kvazi)termín estetično či tvořivost, jejichž užívání zřejmě jen zastírá neschopnost formulovat dané obsahy.
} 


\section{Literatura}

Hazuková, H. (2005). Problémy utváření funkčního slovníku učitele ve výtvarné výchově. In J. Slavík (Ed.), Multidisciplinárni komunikace: Problém a princip všeobecného vzdělávání (pp. 304-326). Praha: UK v Praze.

Janík, T. et al. (2007). Pedagogical content knowledge nebo didaktická znalost obsahu? Brno: Paido. Jeřábek, J., \& Tupý, J. (2007). Rámcový vzdělávaci program pro základní vzděláváni (se změnami provedenými k 1. 9. 2007). Praha: VÚP v Praze.

Pastorová, M., \& Vančát, J. (2004). Výtvarná výchova jako součást vzdělávací oblasti Umění a kultura v připravovaných kurikulárních dokumentech. In T. Šteiglová (Ed.), Výtvarná výchova a mody jeji komunikace, Symposium České sekce INSEA 2002 (pp. 128-138). Olomouc: Vydavatelství UP.

Slavík, J., Lukavský, J., \& Lajdová, A. (2008) Princip imaginace v didaktické znalosti obsahu (na empiricko-výzkumném př́kladu výtvarného projevu). In T. Janík et al., Metodologické problémy výzkumu didaktických znalostí obsahu (pp. 113-127). Brno: Paido.

\section{Kontakt}

Mgr. Petra Šobáňová, Ph.D.

Univerzita Palackého v Olomouci,

Pedagogická fakulta, Katedra výtvarné výchovy

Univerzitní 3-5, 77147 Olomouc

email: petra.sobanova@post.cz

\section{Bibliografické údaje}

Šobáňová, P. (2011). Učitelé výtvarné výchovy a jejich znalosti kurikula. In T. Janík, P. Knecht, \& S. Šebestová (Eds.), Smišsený design v pedagogickém výzkumu: Sborník př́spěvků z 19. výroční konference České asociace pedagogického výzkumu (s. 322-327). Brno: Masarykova univerzita.

Dostupné z: http://www.ped.muni.cz/capv2011/sbornikprispevku/sobanova.pdf

doi: $10.5817 /$ PdF.P210-CAPV-2012-67 